\title{
Redesenhando o Mapa Eleitoral do Brasil: uma proposta de reforma política incremental
}

\author{
Octavio Amorim Neto \\ Escola Brasileira de Administração Pública e de Empresas \\ Fundação Getulio Vargas - RJ \\ Bruno Freitas Cortez \\ Instituto Brasileiro de Geografia e Estatística \\ Samuel de Abreu Pessoa \\ Instituto Brasileiro de Economia \\ Fundação Getulio Vargas - RJ
}

\begin{abstract}
Resumo: Este artigo oferece uma proposta de reforma incremental do sistema eleitoral da Câmara dos Deputados. A natureza incremental da proposta se funda na suposição segundo a qual o sistema político é uma arquitetura complexa e delicada, sendo a possibilidade de piorá-lo com mudanças ambiciosas e intempestivas bem maior do que a de aperfeiçoá.lo. A proposta mantém o sistema de representação proporcional com lista aberta, mas altera duas variáveis-chave, uma vez que reduz a magnitude média das circunscrições eleitorais e estabelece uma regra proporcional de distribuição de cadeiras entre partidos coligados. A operacionalização da reforma leva a um novo desenho do mapa eleitoral do país, com circunscrições eleitorais menores dentro de 12 estados. 0 artigo também apresenta os resultados de um exercício de simulação feito com base nos dados das eleições de 2006 que recalcula a composição partidária da Câmara dos Deputados a partir das regras aqui preconizadas.
\end{abstract}

Palavras-chave: Câmara dos Deputados; representação proporcional com lista aberta; fragmentação legislativa; reforma eleitoral; incrementalismo

\begin{abstract}
This article presents a proposal for an incremental reform of the electoral system of the Chamber of Deputies. The incremental nature of the proposal rests on the assumption that this political system is a complex and delicate architecture, and therefore, abrupt and ambitious changes are more likely to make it worse than to improve it. The proposal advocated here maintains the current system of open-list proportional representation, but it changes two key variables of this electoral system, since it reduces its average district magnitude and establishes a proportional distribution of seats among parties that form electoral coalitions. The way the reform is operationalized leads to a redesign of the electoral map of the country, with smaller districts within 12 states. The article also presents the results of a simulation exercise based on data from the 2006 elections, whereby the party makeup of the Chamber of Deputies is recalculated according to the rules proposed here.
\end{abstract}

Keywords: Chamber of Deputies, open-list proportional representation; legislative fragmentation; electoral reform; incrementalism 


\section{Introdução ${ }^{1}$}

A reforma do sistema político tem sido um tema cada vez mais presente na pauta de debates sobre os grandes desafios nacionais. Em primeira análise, poucas instituições brasileiras parecem padecer de tantos e tão sérios defeitos quanto o sistema eleitoral-partidário. O cidadão brasileiro, em geral, tem a impressão de que os partidos e políticos, nos diversos níveis da Federação, estão imersos em permanente jogo de interesses escusos, em que a busca de benefícios pessoais, ou para grupos de pressão, sobrepuja esmagadoramente a preocupação com o bem público. Neste contexto, a reforma política surge como se fosse um imperativo jamais enfrentado pela sociedade e pelo Congresso - e, consequentemente, como símbolo de uma suposta letargia institucional que explicaria, em boa medida, as nossas mazelas.

Neste artigo, com base em verificações da ciência política, argumentamos que aquela visão não é correta, conquanto não seja completamente destituída de razão. Não há dúvida quanto o sistema político brasileiro ser repleto de problemas, mas, como se verá na próxima seção, existe uma espécie de equilíbrio entre distorções de sentido contrário, cuja resultante tem alguma funcionalidade. Essa montagem singular do sistema político brasileiro não é uma aberração. Em um grande número de países, observa-se uma construção histórica similar. Os sistemas políticos, de uma forma geral, apresentam sucessivas e graduais adaptações que podem criar uma lógica funcional por cima de um arcabouço institucional formado em virtude de razões históricas já superadas.

No Brasil, é preciso prosseguir neste processo de revisão permanente do nosso sistema eleitoral-partidário, não com uma grande reforma que reconstrua todo o "edifício a partir da estaca zero", mas, sim, por meio de medidas pontuais, cirúrgicas e refletidas. Dito isso, este artigo está organizado da seguinte maneira. Após um diagnóstico do funcionamento do sistema político brasileiro apresentado na segunda seção, apresentamos, na seção seguinte, uma proposta de reforma no sentido acima apontado. A proposta mantém o sistema de representação proporcional com lista aberta, mas redesenha parte do mapa eleitoral do país, alterando também a regra de distribuição das cadeiras no interior das coligações eleitorais. Esta proposta se funda na suposição de que o sistema político é uma arquitetura complexa e delicada. Portanto, a possibilidade de piorá-lo com

\footnotetext{
1 Os autores agradecem os comentários e sugestões oferecidos por dois pareceristas anônimos e o financiamento dado a esta pesquisa pelo Instituto Brasileiro de Economia (IBRE), da Fundação Getúlio Vargas no Rio de Janeiro. Uma versão preliminar deste trabalho foi apresentada no seminário Eleições, Partidos e Reforma Política, realizado no Instituto Maurício de Nassau, Recife, nos dias 3 e 4 de agosto de 2009, e numa palestra ministrada no Instituto Legislativo Brasileiro, Brasília, no dia 6 de outubro de 2009.
} 
mudanças ambiciosas e intempestivas é bem maior do que a de aperfeiçoá-lo. Em seguida, na quarta seção, apresentamos os resultados de um exercício de simulação feito com base nos dados das eleições de 2006, por meio do qual recalculamos a composição partidária da Câmara dos Deputados com as regras defendidas no artigo. A última seção discute os objetivos políticos que podem ser alcançados pela reforma preconizada.

\section{O Presidencialismo de Coalizão}

Iniciamos a análise do sistema político nacional citando o artigo clássico e seminal de Sérgio Abranches (1988). No texto, a expressão "presidencialismo de coalizão" indica certo sincretismo entre o presidencialismo e o parlamentarismo. Assim, temos uma presidência sempre às voltas com a costura de maiorias parlamentares, numa interação cotidiana e íntima com deputados e senadores que lembra os regimes parlamentaristas. A análise de Barry Ames (2001), em certo sentido, aprofunda esta visão, ao identificar a dificuldade do Executivo e dos líderes partidários em obter a cooperação dos representantes dos partidos, uma vez que muitos atores políticos têm poder de veto sobre as decisões a serem tomadas (basta pensar nos "caciques" nas duas casas do Congresso).

A literatura acadêmica sugere que aquelas características estão fortemente ligadas a alguns elementos do nosso sistema eleitoral. Um dos principais é a grande dimensão das nossas circunscrições eleitorais, que são os próprios estados, cuja representação na Câmara de Deputados varia de 8 a 70 parlamentares. Outros traços fundamentais do nosso arranjo político são o voto proporcional e o voto nominal com lista aberta (ainda que este seja facultativo, já que se pode votar na legenda).

Esse desenho institucional, em interação com uma sociedade heterogênea, leva a uma elevada fragmentação legislativa, tal qual indicam vários estudos ${ }^{2}$. Como? Um sistema eleitoral permissivo - isto é, com uma baixa barreira de entrada gerada por um grande número de cadeiras disputadas nas circunscrições eleitorais - facilita a obtenção de votos por parte de pequenas legendas, porque os eleitores facilmente intuem que os votos dados a estas têm boas chances de eleger pelo menos um parlamentar. Por sua vez, as pequenas legendas serão tanto mais numerosas quanto mais heterogênea for a sociedade, seja em termos socioeconômicos ou culturais ou regionais ou étnicos ou linguísticos ou religiosos. E

\footnotetext{
2 Ver AMORIM NETO \& COX, 1997; BENOIT, 2002; COX, 1997; DUVERGER, 1951; LIJPHART, 1994; ORDESHOOK \& SHVETSOVA, 1994; RAE, 1967; TAAGEPERA \& SHUGART, 1989; TAAGEPERA \& SHUGART,1993.
} 
se a regra de tradução de votos em cadeiras for proporcional, a percentagem de votos obtida pelas pequenas legendas se transforma em uma percentagem bastante semelhante de cadeiras legislativas. Por exemplo, em uma circunscrição eleitoral socialmente heterogênea com 70 cadeiras e votação proporcional, como é o caso do estado de São Paulo, qualquer partido com apenas 1,4\% dos votos pode-se fazer representar no Congresso Nacional.

De maneira complementar, como demonstra Nicolau (1996), a fragmentação no Brasil também está associada à facilidade de criação de legendas, ao troca-troca partidário e às coligações eleitorais. Por sua vez, o voto nominal com lista aberta amplia ainda mais o cacife de políticos com capacidade de disputar pequenos quinhões eleitorais, uma vez que, em boa medida, tira das lideranças partidárias o poder de definir e hierarquizar as candidaturas. No ambiente formado por aquele conjunto de características, não é de se estranhar que surja um grande número de partidos. Esta fragmentação, por sua vez, torna mais difícil para o presidente da República conseguir uma sólida maioria no Congresso no momento em que é eleito, mesmo com eleições legislativas simultâneas à presidencial.

As implicações deste tipo de sistema político são múltiplas. Há, por exemplo, uma ampla evidência empírica segundo a qual aquelas características estão associadas à elevação do gasto público, do gasto social e da carga tributária, como verifica Mukherjee (2003). O Brasil, diga-se de passagem, destaca-se claramente nestas características em comparação com os seus pares. $O$ aumento da despesa pública e da carga tributária deriva, evidentemente, da permanente necessidade do Executivo de angariar sustentação política, como mostram Amorim Neto (2006) e Schröder (2009). Isto significa atender às demandas dos inúmeros grupos de pressão representados por políticos que sabem que uma fatia relativamente pequena do eleitorado, quando bem atendida, é suficiente para leválos ou mantê-los no Legislativo.

Outro problema que surge em um arcabouço político como o brasileiro é o da competição intrapartidária. Como as lideranças nacionais dos partidos não controlam as candidaturas, os colegas de sigla, nos estados, tendem a disputar acirradamente os votos do eleitorado simpatizante daquela agremiação. Para isto, evidentemente, não basta defender as cores, a ideologia e o programa do partido, porque esta plataforma eleitoral estimulará os eleitores a votar na legenda, mas não naquele candidato específico. O postulante à vaga na Câmara, pelo contrário, tem que procurar a diferenciação ante seus colegas de partido, sendo isto, evidentemente, um estímulo para que o candidato não enfatize a linha partidária, como mostra Nicolau (2006).

Os estudos indicam ainda que quanto maior for a circunscrição eleitoral, maior será a competição intrapartidária, uma vez que o grande número de vagas oferecidas é um chamariz para que muitas candidaturas sejam postuladas. $\mathrm{Na}$ 
mesma linha de causalidade, os custos de campanha aumentam, já que, envolvidos neste tipo de competição de cada um contra todos, os candidatos sabem que o dinheiro pode ser o mais eficaz dos diferenciais. Segundo Samuels (2006), o custo das campanhas presidenciais no Brasil é maior do que o das estadunidenses, e o custo das campanhas legislativas é três vezes maior em termos per capita, levandose em conta a paridade do poder de compra (PPP). Altos custos de campanha e nível elevado de gastos públicos, por sua vez, são fatores que podem impulsionar a corrupção, que, desta forma, também está ligada à combinação de representação proporcional, listas abertas e grandes circunscrições.

Uma última consequência das características do sistema eleitoral brasileiro, segundo Carvalho (2003) e Monroe e Rose (2002), é o número reduzido de representantes das áreas metropolitanas. Embora sejam mercados com número abundante de eleitores, são muito fragmentados. Por conta disso, é mais fácil para os candidatos terem base política nas regiões interioranas e buscarem alguns votos nos grandes centros do que construírem fortes bases políticas nas capitais e grandes cidades dos estados. A conseqüência imediata é o déficit de representação das metrópoles.

A fragmentação e o personalismo na política nacional são amplificados pelo horário eleitoral gratuito e pelas regras muito frouxas de acesso aos recursos do fundo partidário, as quais reduzem significativamente o custo de criação de novas agremiações partidárias. Com poucas barreiras à entrada de novos atores, o sistema torna-se permissivo, havendo, portanto, mais partidos do que interesses vitais a serem representados. Na verdade, dado o personalismo e o baixo comprometimento programático de um número expressivo de políticos, a profusão de siglas não representa nem mesmo os interesses que, de fato, deveriam estar organizados no parlamento. Um exemplo desta distorção é a presença das chamadas "bancadas" ruralista, da saúde ou da educação, que agem de forma mais coerente - em algumas votações - do que os partidos, e cujos integrantes esparramam-se pelas mais diversas agremiações. Não seria de se esperar, evidentemente, que os interesses de qualquer um daqueles setores estivessem representados por apenas um partido. Mas o mais saudável seria a existência de distintas posições partidárias relativas a cada um deles, e que os políticos votassem de acordo com a sua filiação partidária, e não com as determinações de "bancadas" suprapartidárias.

Todos esses problemas não sugerem, como afirmamos de início, que o sistema político brasileiro seja imprestável. Na verdade, este é um terreno onde cada característica funciona como moeda de duas faces, e em que, frequentemente, um defeito tem uma contrapartida positiva, e vice-versa. A permissividade do sistema, mencionada acima, tem uma faceta democrática, já que as minorias conseguem representação. No sistema inglês, de voto distrital puro - o antípoda do 
brasileiro -, é sabido que apenas três partidos estão solidamente representados no Parlamento, sendo praticamente impossível que uma importante corrente de opinião, os verdes, por exemplo, transforme-se em partido legislativo, como aconteceu em tantos países. Já a forte competição eleitoral, mesmo quando ocorre no interior dos partidos, é um antídoto contra o monopólio da seleção das candidaturas pelas lideranças partidárias, sendo também, como tal, um elemento democratizante.

Mais significativo, porém, é o fato de haver fartas evidências segundo as quais o sistema de governo brasileiro funciona com razoável efetividade. Os trabalhos de Figueiredo e Limongi (2006), de Limongi (2006), e de Santos (2003) indicam que o Executivo tem capacidade de pautar o Congresso e fazer aprovar a sua agenda legislativa. A ideia, por exemplo, de que uma reforma mais profunda da Previdência não é aprovada por causa de impasses políticos é apenas parcialmente verdadeira, já que outra razão plausível é simplesmente o fato de a sociedade não estar plenamente convencida da sua necessidade. Assim, o sistema político parece estar funcionando como canal de transmissão das preferências do eleitorado para as decisões governamentais, ainda que numa direção criticada pelos especialistas em contas públicas.

\section{Uma Presidência Poderosa}

Quando se tenta compreender a origem daquela surpreendente funcionalidade, é importante notar que as principais características do atual sistema - os estados como circunscrições eleitorais, o voto proporcional e a lista aberta - existiam também no período democrático de 1946 a 1964. Todavia, aqueles foram tempos de forte instabilidade e radicalização políticas, que contrastam com a experiência atual. A taxa de sucesso do Executivo na aprovação de projetos na fase contemporânea da democracia brasileira é de $85 \%$, próxima da obtida em sistemas parlamentaristas, e muito maior do que a que se verificou entre 1945 e 1964 (ver FIGUEIREDO e LIMONGI, 2006).

Segundo Figueiredo e Limongi, a diferença entre os dois regimes democráticos reside no fato de o atual ter mantido as extensas prerrogativas legislativas conferidas ao presidente pelos militares. Assim, uma série de faculdades dos presidentes do período pós-autoritário não existia para aqueles que governaram antes de 1964: ter iniciativas exclusivas em projetos orçamentários e tributários; iniciar emendas constitucionais; editar medidas provisórias; editar leis sob requerimento de delegação do Congresso; solicitar urgência; e impor restrições a emendas parlamentares. Figueiredo e Limongi mostram ainda que os líderes partidários da fase democrática atual também detêm uma série de poderes que os seus antecessores, antes do regime militar, não possuíam: determinar a agenda do 
plenário; representar a bancada; retirar projetos de lei das comissões por meio de requerimento de urgência; e indicar e substituir membros das comissões mistas, de CPIs e das comissões do orçamento.

Desta forma, é possível afirmar que, no atual período democrático, o excesso de fragmentação e personalismo resultantes das regras do jogo político é contrabalançado por poderes excepcionalmente fortes do Executivo e das lideranças partidárias, quando se compara com o período de 1946 a 1964. Assim, alguns dos mais citados "defeitos" do sistema político nacional, como a ampla autoridade constitucional do presidente e a fragmentação do Congresso, são, na verdade, características que, até certo ponto, se neutralizam.

Com efeito, qualquer sistema político é o resultado de um equilíbrio complexo e delicado entre inúmeros fatores institucionais e sociais. Alguns dos mais importantes são: (1) a modalidade de formação das chapas eleitorais (existência ou não de eleições primárias); (2) a estrutura da cédula, isto é, se o voto é em lista ou em nomes e, no caso de listas, se elas são abertas, fechadas ou flexíveis; (3) a aplicação da regra majoritária ou da proporcional para a tradução de votos em cadeiras; (4) a magnitude das circunscrições eleitorais; (5) a coincidência ou não do calendário eleitoral para as eleições majoritária (Executivo) e proporcional (Legislativo), que, quando acontece, tende a reduzir a corrupção e elevar a responsabilização (SAMUELS, 2004, TAVITS 2007); (6) os poderes legislativos do chefe do Executivo e dos líderes partidários; (7) a forma autorizativa ou impositiva de execução do orçamento e o espaço do Executivo para negociar emendas; (8) e, last but not least, a estrutura de clivagens e o nível de heterogeneidade social.

Como vimos no caso da combinação de extensos poderes do Executivo e dos líderes partidários com alta fragmentação legislativa, a dinâmica política resultante é um complexo sistema ecológico, cujo equilíbrio envolve o funcionamento de todos os componentes. E é por isso que qualquer alteração tem que ser avaliada com todo o cuidado. A título de exemplo, quando se pensa na introdução da lista fechada, a qual aumentaria ainda mais o cacife das lideranças partidárias, dever-seia incluir no projeto algum mecanismo de democratização na seleção de candidaturas, como as eleições primárias, que colocaria limites ao poder dos líderes.

Outro risco é o de promover alterações grandes e custosas em termos políticos, mas que, de fato, não atacam o cerne do problema que se propõem a resolver. Por exemplo, a introdução de um sistema distrital misto não reduzirá a fragmentação partidária se forem mantidos os estados como circunscrições eleitorais para a parte proporcional da votação. E há, finalmente, o perigo de se anular inadvertidamente alguma característica positiva do sistema. Se, como querem alguns, a reeleição for extinta e o mandato de cinco anos reintroduzido, não 
haverá mais a coincidência entre as eleições parlamentares e presidenciais. Como mostram Samuels (2004) e Tavits (2007), aquela simultaneidade atrela, na ótica do eleitorado, os legisladores à plataforma do Executivo, aumentando a responsabilização do Congresso em relação ao sucesso ou ao fracasso do governo. Todos estes exemplos indicam a dificuldade na promoção de mudanças institucionais, deixando claro não haver uma solução única e inequívoca para resolver os grandes problemas políticos nacionais.

A questão da reforma política é, pois, muito mais complexa do que transparece no debate que chega aos meios de comunicação, e que, ao contrário do que a maioria supõe, o sistema brasileiro não é de todo disfuncional. Entretanto, é inegável que há problemas, como a sucessão de escândalos, o excesso de partidos, as despesas de campanha muito elevadas, o elevado gasto público, o forte personalismo e a alta instabilidade ministerial (com relação a este último aspecto, ver Amorim Neto, 2006). Diante do desafio de melhorar o sistema político brasileiro, a melhor opção são as alterações incrementais, com objetivos muito definidos e que não sejam demasiado ambiciosos. Parece-nos que reduzir a excessiva fragmentação legislativa, mas sem eliminar a representação proporcional, e minorar a competição intrapartidária seriam metas consensuais, populares e que certamente teriam um efeito positivo na operação do regime representativo.

Criar mecanismos que propiciem um aumento na transparência do financiamento eleitoral seria também uma medida positiva. A título de exemplo, a introdução de um limite para doações por pessoas jurídicas e a melhoria nos controles do 'caixa dois' - que poderiam incluir a prestação de contas contínua, e quase simultânea, ao gasto, na internet - poderiam ser uma saída.

Essas ideias têm que ser discutidas com calma e introduzidas gradualmente, sem necessidade de se acenar com grandiosos planos de reforma política. Neste debate, talvez seja exagero aplicar a máxima futebolística segundo a qual "não se mexe em time que está ganhando." Por outro lado, é bastante pertinente afirmar que mudanças em um sistema cujo funcionamento não é desastroso devem ser feitas com cuidado e moderação.

Assim, a seguir, oferecemos uma possível operacionalização de uma proposta originalmente feita por Lima Júnior e Santos (1991) no sentido da redução da magnitude (isto é, o número de cadeiras disputadas) das nossas circunscrições (ou distritos, de acordo com o jargão da ciência política) eleitorais, sem tocar no princípio constitucional da representação proporcional e na lista aberta. Segundo Lima Júnior e Santos:

“... a solução mais simples para atenuar os efeitos perversos para os partidos e eleitores, decorrentes de características contextuais da competição eleitoral, isto é, da diversidade no tamanho das bancadas 
e da força relativa dos partidos, consistiria em levar mais a sério o princípio da isomorfia entre população e cadeiras, tornando constante esta relação: a magnitude dos distritos eleitorais e o número de deputados por ele eleitos seria o mesmo em todo o país. Os estados federados deixariam de ser a base territorial sobre a qual as cadeiras são alocadas, criando-se novas unidades territoriais - os distritos - que elegeriam, cada uma, o mesmo número de deputados. Conseqüentemente, não só desapareceriam as iniqüidades apontadas, mas também o princípio da federação desapareceria da representação política na Câmara dos Deputados, que passaria a ser o locus privilegiado, diferentemente do Senado que é o órgão de representação das unidades federadas, da representação do povo" (LIMA e SANTOS, 1991).

$\mathrm{Na}$ nossa operacionalização da proposta de Lima Júnior e Santos, afrouxamos a noção segundo a qual o princípio da federação desapareceria da representação política na Câmara dos Deputados, uma vez que, consoante nossa abordagem gradual e cautelosa da reforma política, o abandono do princípio da federação poderia gerar celeumas demais. Assim, o que fazemos é redesenhar a geografia eleitoral dos 12 maiores estados, justamente aqueles que têm 16 ou mais cadeiras na Câmara, permitindo que sejam recortados em circunscrições com magnitudes que variam entre 8 e $11^{3}$. Portanto, também afrouxamos o princípio da isomorfia entre população e cadeiras advogado por Lima Júnior e Santos, desta vez não por prudência política, mas apenas porque seria impossível gerar números inteiros se dividíssemos as cadeiras de cada um dos 12 estados pelo mesmo valor. De qualquer modo, é muito melhor que a magnitude das circunscrições eleitorais varie entre 8 e 12 do que entre 8 e 704. Convém ainda destacar que mantemos inalterado o peso de cada estado da Federação na Câmara dos Deputados.

De maneira complementar, ao adotarmos um critério de agregação dos municípios que formam as novas circunscrições eleitorais, optamos pela maximização da homogeneidade socioeconômica, com base na verificação segundo a qual é a combinação de alta heterogeneidade social com circunscrições eleitorais de grande magnitude que leva à alta fragmentação legislativa (AMORIM NETO e COX 1997; BENOIT 2002). Assim, procuramos criar circunscrições as mais homogêneas possíveis, de acordo com o que cremos ser a principal clivagem política do país, qual seja, a socioeconômica. É claro que o Brasil tem outras

\footnotetext{
${ }^{3}$ O trabalho clássico de Taagepera e Shugart (1993) mostra que, dentro desta faixa de magnitude, os sistemas partidários tendem a ter uma fragmentação legislativa moderada.

4 A variação da magnitude dos estados não redesenhados oscila entre 8 e 12. Apenas um estado, a Paraíba, tem mais de 11 cadeiras, 12. Por isso, sob a nossa proposta, a variação da magnitude das circunscrições se dá entre 8 e 12.
} 
clivagens (étnica, religiosa e regional), mas estas não são tão importantes quanto aquela.

Consideraremos também em nosso exercício outra reforma incremental. As coligações partidárias para as eleições proporcionais são vistas como outro fator que contribui para elevar a fragmentação legislativa, como indica Nicolau (1996). Além disso, a regra de distribuição das cadeiras no interior das coligações fere o princípio da proporcionalidade. Nossa proposta advoga a manutenção do instituto das coligações partidárias para as eleições legislativas, mas altera a regra de distribuição das cadeiras de modo a torná-la proporcional. Isto é, a distribuição das cadeiras intracoligações será proporcional à votação de cada partido integrante das alianças eleitorais. Ou seja, como as coligações, sob as regras atuais, favorecem os pequenos partidos que por si só não conseguem atingir o quociente eleitoral, sob a regra que propomos, deixa de existir o estímulo espúrio para que os pequenos partidos predem os grandes partidos que aceitem com eles se coligar.

Por último, em nossa proposta, as coligações são mantidas porque elas podem ser úteis para adiantar o processo de construção da base de sustentação dos governos antes do primeiro turno das eleições presidenciais, oferecendo, também, uma compensação aos pequenos partidos pelo aumento dos quocientes eleitorais gerado pela redução na magnitude das circunscrições eleitorais.

\section{Redesenhando o Mapa Eleitoral do Brasil}

Esta proposta tem por objetivo a criação de áreas contíguas, chamadas circunscrições eleitorais, para doze unidades da Federação (UF) brasileiras, formadas pela agregação de unidades geográficas menores, em função de algumas variáveis de homogeneidade.

As doze UF trabalhadas são as seguintes: São Paulo, Minas Gerais, Rio de Janeiro, Paraná, Santa Catarina, Rio Grande do Sul, Bahia, Pernambuco, Ceará, Maranhão, Goiás e Pará. De acordo com o total de habitantes, fornecido pelo Censo Demográfico 2000, e o número total de circunscrições eleitorais desejado em cada UF, estimamos a população média que estas circunscrições deveriam ter em cada um destes doze casos, como mostra a Tabela 1, a seguir. 
AMORIM NETO, O.; CORTEZ, B. F.; PESSOA, S. A. Redesenhando o Mapa Eleitoral do Brasil:...

Tabela 1

Unidades da Federação trabalhadas e as respectivas populações médias das menores circunscrições eleitorais a serem criadas

\begin{tabular}{|l|c|}
\hline $\begin{array}{l}\text { Unidade da } \\
\text { Federação }\end{array}$ & $\begin{array}{l}\text { População média da menor } \\
\text { circunscrição }^{\mathbf{5}}\end{array}$ \\
\hline São Paulo & 4.221 .694 habitantes \\
\hline Minas Gerais & 2.683 .724 \\
\hline Rio de Janeiro & 2.518 .474 \\
\hline Paraná & 3.187 .819 \\
\hline Santa Catarina & 2.678 .180 \\
\hline Rio Grande do Sul & 3.311 .034 \\
\hline Bahia & 2.774 .752 \\
\hline Pernambuco & 2.533 .870 \\
\hline Ceará & 3.715 .331 \\
\hline Maranhão & 2.486 .649 \\
\hline Goiás & 2.351 .517 \\
\hline Pará & 2.910 .384 \\
\hline
\end{tabular}

Estes quantitativos populacionais foram comparados com a população de cada município dentro das UF. Se um município possuísse um número de habitantes, segundo o Censo 2000, superior ao valor explicitado na Tabela 1, ele poderia ser trabalhado separadamente, de modo que o próprio município formasse uma ou mais circunscrições eleitorais. Neste caso, deveria ser escolhida uma divisão geográfica dentro do município, para que a mesma pudesse ser agregada e formasse as circunscrições eleitorais.

Feita a análise, verificamos que os municípios de São Paulo (com 10.434.252 habitantes) e do Rio de Janeiro (com 5.857.904 habitantes), poderiam dar origem a duas circunscrições eleitorais dentro de suas respectivas unidades da Federação. O número de circunscrições a serem criados, em cada UF, está disposto na Tabela 2.

\footnotetext{
${ }^{5}$ As circunscrições eleitorais podem ser classificadas como circunscrições de 8, 9, 10 ou 11 deputados. A variável contida na tabela refere-se à circunscrição com menor número de deputados dentro da UF.
} 
OPINIÃO PÚBLICA, Campinas, vol. 17, no 1, Junho, 2011 , p.45-75

Tabela 2

Número de circunscrições eleitorais a serem criadas por unidade da Federação

\begin{tabular}{|l|c|c|}
\hline \multirow{2}{*}{\multicolumn{1}{c|}{$\begin{array}{c}\text { Unidade da } \\
\text { Federação }\end{array}$}} & \multicolumn{2}{c|}{ Circunscrições a serem criadas } \\
\cline { 2 - 4 } & Total & Observação \\
\hline São Paulo & 8 & 2 no município de São Paulo \\
\hline Minas Gerais & 6 & \\
\hline Rio de Janeiro & 5 & 2 no município do Rio de Janeiro \\
\hline Paraná & 3 & \\
\hline Santa Catarina & 2 & \\
\hline Rio Grande do Sul & 3 & \\
\hline Bahia & 4 & \\
\hline Pernambuco & 3 & \\
\hline Ceará & 2 & \\
\hline Maranhão & 2 & \\
\hline Goiás & 2 & - \\
\hline Pará & 2 & - \\
\hline
\end{tabular}

O passo seguinte foi a escolha da unidade geográfica, dentro dos municípios do Rio de Janeiro e São Paulo, para o cálculo de suas variáveis de homogeneidade e posterior agregação em circunscrições eleitorais. Uma vez que o sentido político era relevante neste trabalho, procuramos uma subdivisão destes municípios que fosse previamente existente e que tanto o IBGE quanto as prefeituras a utilizassem na divulgação de dados oficiais. Assim, para município do Rio de Janeiro, optamos por trabalhar com as 32 regiões administrativas, enquanto, para São Paulo, optamos por trabalhar com as suas 96 regiões.

Definidos estes pontos, iniciamos o procedimento de agregação das unidades geográficas menores (municípios ou regiões administrativas), em circunscrições eleitorais. Utilizamos os softwares SKATER e ARCVIEW, sendo os seus procedimentos detalhados a seguir.

\section{O SKATER e a sua Execução}

O software SKATER (Spatial Cluster by Tree Edge Removal) foi concebido e programado para definir áreas homogêneas e contíguas a partir do agrupamento de áreas menores, segundo variáveis de homogeneidade. Utilizamos a distância euclidiana entre os valores destas variáveis como padrão de combinação, com a restrição de nenhuma área ser menor que um parâmetro estipulado (variável de 
população). O SKATER trabalha usando a teoria dos grafos e, a partir de uma árvore geradora mínima, poda sucessivamente as arestas com menor grau de similaridade.

Neste trabalho, as áreas menores a serem agregadas são os municípios e as regiões administrativas quando se trabalhou com as Unidades da Federação, e os municípios do Rio de Janeiro e de São Paulo, respectivamente.

As variáveis de homogeneidade utilizadas foram a renda per capita, o Índice de Desenvolvimento Humano Educacional (IDH-E) e o IDH geral, calculados com base no Censo Demográfico 2000. Os valores destas variáveis de homogeneidade foram normalizados para evitar distorções nos intervalos de variação, o que poderia fazer com que uma variável tivesse mais influência que as outras no processo de cálculo da distância.

O limite populacional para o tamanho de cada circunscrição eleitoral é variável em função da unidade da Federação, ou município trabalhado separadamente, em que o mesmo está contido. Em um primeiro momento este limite, para cada UF, foi estabelecido em, aproximadamente, $10 \%$ abaixo do valor contido na Tabela 1, e para os municípios, aproximadamente $10 \%$ abaixo do valor resultante da divisão de seu total populacional pelo número de circunscrições eleitorais a serem criados nos mesmos. Este procedimento visa assegurar graus de liberdade para o SKATER conseguir fazer a divisão do total de áreas desejadas, sem que exista uma variação muito maior do que a esperada no tamanho total destas áreas. Caso, neste primeiro momento, não tenha sido possível atingir o total de áreas desejadas, o limite populacional é posteriormente reduzido. Este procedimento está detalhado a seguir.

É importante mencionar que o SKATER não busca maximizar o número de áreas a serem criadas, mas, sim, homogeneizá-las de acordo com as variáveis de controle, dada uma restrição populacional mínima. Para ter o controle do total de áreas criadas, seria necessário abrir mão da restrição populacional, o que alteraria a natureza do exercício. Assim, caso o software crie um número menor de circunscrições eleitorais do que o total desejado, é possível diminuir o limite mínimo populacional, ou, em último caso, subdividir um ou mais circunscrições eleitorais produzidas pelo SKATER, por algum outro método.

\section{O Uso do ARCVIEW}

O ARCVIEW foi usado com dois objetivos distintos: produzir a lista de vizinhos e a visualização espacial das circunscrições eleitorais em forma de mapas.

A lista de vizinhos é uma peça fundamental de todo o sistema, uma vez que a determinação das circunscrições eleitorais tem como restrição básica a contigüidade das áreas menores que o formam. A obtenção da lista de vizinhos é feita a partir de um programa em AVENUE (linguagem de programação do ARCVIEW 
3.0a). O programa faz a leitura de todos os polígonos de um arquivo SHAPE e produz uma lista de todos os polígonos que tenham um arco comum.

Para evitar que fossem permitidas vizinhanças de topo, ou de vértice (polígonos vizinhos por um único ponto), o algoritmo somente levou em conta vizinhos que tivessem uma linha comum de no mínimo 5\% do perímetro do menor polígono. O formato de apresentação desta lista foi determinado pelo SKATER, o qual necessita receber o par de vizinhos em forma recíproca, ou seja, se, na lista obtida, a área $A$ é vizinha de $B$, deve ser também especificado que a área $B$ é vizinha de A.

Entretanto, tivemos que considerar duas exceções de contiguidade. São os casos do município de Fernando de Noronha, em Pernambuco, e do município de Ilhabela, em São Paulo. Os dois municípios são ilhas, logo não existe contiguidade com nenhum outro daquela unidade da Federação, e, desta forma, se o critério de contiguidade não fosse contornado, estes dois municípios não fariam parte de nenhuma circunscrição eleitoral. Assim, criamos vizinhanças artificiais com os municípios litorâneos mais próximos, de modo a permitir ao software agregá-los normalmente. Para Fernando de Noronha, criamos vizinhanças artificiais com os municípios de Goiana, Itamaracá e Igarassu, enquanto, para Ilhabela, geramos vizinhanças artificiais com os municípios de São Sebastião e Caraguatatuba.

\section{A Geração das Circunscrições Eleitorais}

De posse dos arquivos com as variáveis de homogeneidade e da lista de vizinhança para os 14 recortes geográficos de trabalho (as 12 UF e os municípios do Rio de Janeiro e de São Paulo), iniciamos o procedimento de execução dos mesmos no SKATER. Como mencionamos acima, nem sempre, na primeira execução, foi possível obter o número de circunscrições eleitorais desejado. Neste caso, uma nova execução foi realizada, diminuindo o limite populacional mínimo por circunscrição. Os detalhes e parâmetros de execução para os 14 recortes geográficos se encontram explicitados na Tabela 3: 
AMORIM NETO, O.; CORTEZ, B. F.; PESSOA, S. A. Redesenhando o Mapa Eleitoral do Brasil:...

Tabela 3

Execução do SKATER para os recortes geográficos trabalhados

\begin{tabular}{|c|c|c|c|c|c|}
\hline Execução & $\begin{array}{c}\text { Recorte } \\
\text { Geográfico }\end{array}$ & $\begin{array}{c}\text { Limite } \\
\text { Populacional }\end{array}$ & $\begin{array}{l}\text { Circuns- } \\
\text { crições } \\
\text { desejadas }\end{array}$ & $\begin{array}{l}\text { Circuns- } \\
\text { crições } \\
\text { criadas }\end{array}$ & $\begin{array}{l}\text { Tamanho das } \\
\text { Circunscrições } \\
\text { (menor e maior) }\end{array}$ \\
\hline 1 & UF São Paulo ${ }^{6}$ & 3.700.000 hab & 6 & 4 & 4.564.338 a 8.619.266 hab \\
\hline 2 & UF São Paulo & 3.300 .000 & 6 & 5 & 3.360 .511 a 8.094 .503 \\
\hline 3 & UF São Paulo & 2.600 .000 & 6 & 6 & 2.641 .990 a 8.094 .503 \\
\hline 1 & $\begin{array}{c}\text { Munic. São } \\
\text { Paulo }\end{array}$ & 4.700 .000 & 2 & 2 & 5.042 .291 a 5.391 .961 \\
\hline 1 & UF Minas Gerais & 2.400 .000 & 6 & 6 & 2.428 .098 a 3.666 .791 \\
\hline 1 & $\begin{array}{c}\text { UF Rio de } \\
\text { Janeiro }^{7} \\
\end{array}$ & 2.300 .000 & 3 & 3 & 2.329 .547 a 3.581 .065 \\
\hline 1 & $\begin{array}{c}\text { Munic. Rio de } \\
\text { Janeiro }\end{array}$ & 2.650 .000 & 2 & 1 & Não foi possível a divisão \\
\hline 2 & $\begin{array}{c}\text { Munic. Rio de } \\
\text { Janeiro }\end{array}$ & 2.300 .000 & 2 & 2 & 2.335 .780 a 3.522 .124 \\
\hline 1 & UF Paraná & 2.850 .000 & 3 & 3 & 2.944 .271 a 3.615 .346 \\
\hline 1 & $\begin{array}{l}\text { UF Santa } \\
\text { Catarina } \\
\end{array}$ & 2.400 .000 & 2 & 2 & 2.550 .087 a 2.806 .273 \\
\hline 1 & $\begin{array}{l}\text { UF Rio Grande } \\
\text { do Sul }\end{array}$ & 3.000 .000 & 3 & 2 & 4.710 .815 a 5.476 .983 \\
\hline 2 & $\begin{array}{c}\text { UF Rio Grande } \\
\text { do Sul }\end{array}$ & 2.700 .000 & 3 & 3 & 2.721 .552 a 4.710 .815 \\
\hline 1 & UF Bahia & 2.450 .000 & 4 & 3 & 3.774 .928 a 5.050 .920 \\
\hline 2 & UF Bahia & 2.100 .000 & 4 & 4 & 2.109 .462 a 4.244 .402 \\
\hline 1 & UF Pernambuco & 2.250 .000 & 3 & 3 & 2.333 .562 a 2.961 .679 \\
\hline 1 & UF Ceará & 3.350 .000 & 2 & 1 & Não foi possível a divisão \\
\hline 2 & UF Ceará & 2.900 .000 & 2 & 2 & 2.925 .441 a 4.505 .220 \\
\hline 1 & UF Maranhão & 2.250 .000 & 2 & 2 & 2.291 .134 a 3.360 .341 \\
\hline 1 & UF Goiás & 2.100 .000 & 2 & 1 & Não foi possível a divisão \\
\hline 2 & UF Goiás & 1.700 .000 & 2 & 2 & 1.716 .874 a 3.286 .354 \\
\hline 1 & UF Pará & 2.650 .000 & 2 & 2 & 2.782 .324 a 3.409 .983 \\
\hline
\end{tabular}

${ }^{6}$ Excluído o município de São Paulo.

7 Excluído o município do Rio de Janeiro. 
De acordo com a Tabela 3, verificamos que para São Paulo, Rio Grande do Sul, Bahia, Ceará e Goiás, bem como para o município do Rio de Janeiro, o SKATER não conseguiu produzir, em um primeiro momento, o número de circunscrições eleitorais desejado. Assim, o limite populacional mínimo foi alterado, de forma a se obter uma configuração com este número de circunscrições. Este procedimento, embora obtenha o total de áreas contíguas desejadas, pode acarretar um aumento na diferença entre os tamanhos (totais populacionais) das mesmas. Entretanto, dependendo da finalidade do trabalho, se a diferença é muito acentuada, esta solução pode não ser a mais indicada.

A solução alternativa seria aproveitar as áreas criadas pelo SKATER e dividir algumas destas áreas (em geral, as maiores em termos populacionais), por algum outro método ou software. Tomando como exemplo o caso da Bahia, seria possível utilizar a configuração 1 (proveniente da execução 1), aproveitando-se as 3 áreas criadas pelo SKATER e escolhendo-se uma delas e subdividindo-a por outro método, ou então simplesmente utilizar a configuração 2 (proveniente da execução 2) que gerou o número de áreas desejado.

Resultados

Representadas nos mapas das circunscrições eleitorais a Tabela 4 mostra a magnitude de cada nova circunscrição. O estado de São Paulo, por exemplo, passaria a ter oito circunscrições eleitorais, sendo duas dentro da capital. Três circunscrições teriam, cada uma, dez deputados, e cinco circunscrições possuiriam, cada uma, oito representantes. Minas Gerais contaria com seis circunscrições, enquanto o Rio de Janeiro teria cinco, sendo duas dentro da capital. Em geral, o desenho das circunscrições criadas parece guardar alguma coerência geográfica, à exceção do Skater 1 da Bahia, do Skater 2 do Pará, do Skater 3 do Rio de Janeiro, e do Skater 1 de São Paulo. Isso significa que a aplicação homogênea do nosso critério de agregação dos municípios precisa de retificações ad hoc, em nome da coerência política e geográfica. 
AMORIM NETO, O.; CORTEZ, B. F.; PESSOA, S. A. Redesenhando o Mapa Eleitoral do Brasil....

Tabela 4

Número de Cadeiras por Circunscrição Eleitoral

\begin{tabular}{|c|c|c|c|}
\hline Unidade da Federação & Circunscrição Eleitoral & $\mathrm{N}^{\circ}$ de Cadeiras & Observação \\
\hline Bahia & Skater 1 & 10 & $\cdot$ \\
\hline Bahia & Skater 2 & 10 & - \\
\hline Bahia & Skater 3 & 8 & - \\
\hline Bahia & Skater 4 & 11 & - \\
\hline Ceará & Skater 1 & 11 & - \\
\hline Ceará & Skater 2 & 11 & - \\
\hline Goiás & Skater 1 & 8 & - \\
\hline Goiás & Skater 2 & 9 & - \\
\hline Maranhão & Skater 1 & 10 & - \\
\hline Maranhão & Skater 2 & 8 & - \\
\hline Minas Gerais & Skater 1 & 8 & - \\
\hline Minas Gerais & Skater 2 & 10 & - \\
\hline Minas Gerais & Skater 3 & 8 & - \\
\hline Minas Gerais & Skater 4 & 10 & - \\
\hline Minas Gerais & Skater 5 & 8 & - \\
\hline Minas Gerais & Skater 6 & 9 & - \\
\hline Pará & Skater 1 & 8 & - \\
\hline Pará & Skater 2 & 9 & - \\
\hline Pernambuco & Skater 1 & 8 & - \\
\hline Pernambuco & Skater 2 & 9 & - \\
\hline Pernambuco & Skater 3 & 8 & - \\
\hline Paraná & Skater 1 & 10 & . \\
\hline Paraná & Skater 2 & 10 & - \\
\hline Paraná & Skater 3 & 10 & . \\
\hline Rio de Janeiro & Skater 1 & 9 & - \\
\hline Rio de Janeiro & Skater 2 & 10 & - \\
\hline Rio de Janeiro & Skater 3 & 9 & - \\
\hline Rio de Janeiro & Skater 9.1 & 9 & Município do RJ \\
\hline Rio de Janeiro & Skater 9.2 & 9 & Município do RJ \\
\hline Rio Grande do Sul & Skater 1 & 10 & - \\
\hline Rio Grande do Sul & Skater 2 & 10 & - \\
\hline Rio Grande do Sul & Skater 3 & 11 & - \\
\hline Santa Catarina & Skater 1 & 8 & - \\
\hline Santa Catarina & Skater 2 & 8 & - \\
\hline São Paulo & Skater 1 & 8 & - \\
\hline
\end{tabular}


OPINIÃO PÚBLICA, Campinas, vol. 17, no 1, Junho, 2011 , p.45-75

\begin{tabular}{|l|c|c|c|}
\hline São Paulo & Skater 2 & 10 & $\cdot$ \\
\hline São Paulo & Skater 3 & 8 & $\cdot$ \\
\hline São Paulo & Skater 4 & 8 & $\cdot$ \\
\hline São Paulo & Skater 5 & 8 & $\cdot$ \\
\hline São Paulo & Skater 6 & 8 & $\cdot$ \\
\hline São Paulo & Skater 9.1 & 10 & Município de SP \\
\hline São Paulo & Skater 9.2 & 10 & Município de SP \\
\hline
\end{tabular}

Mapas das circunscrições eleitorais
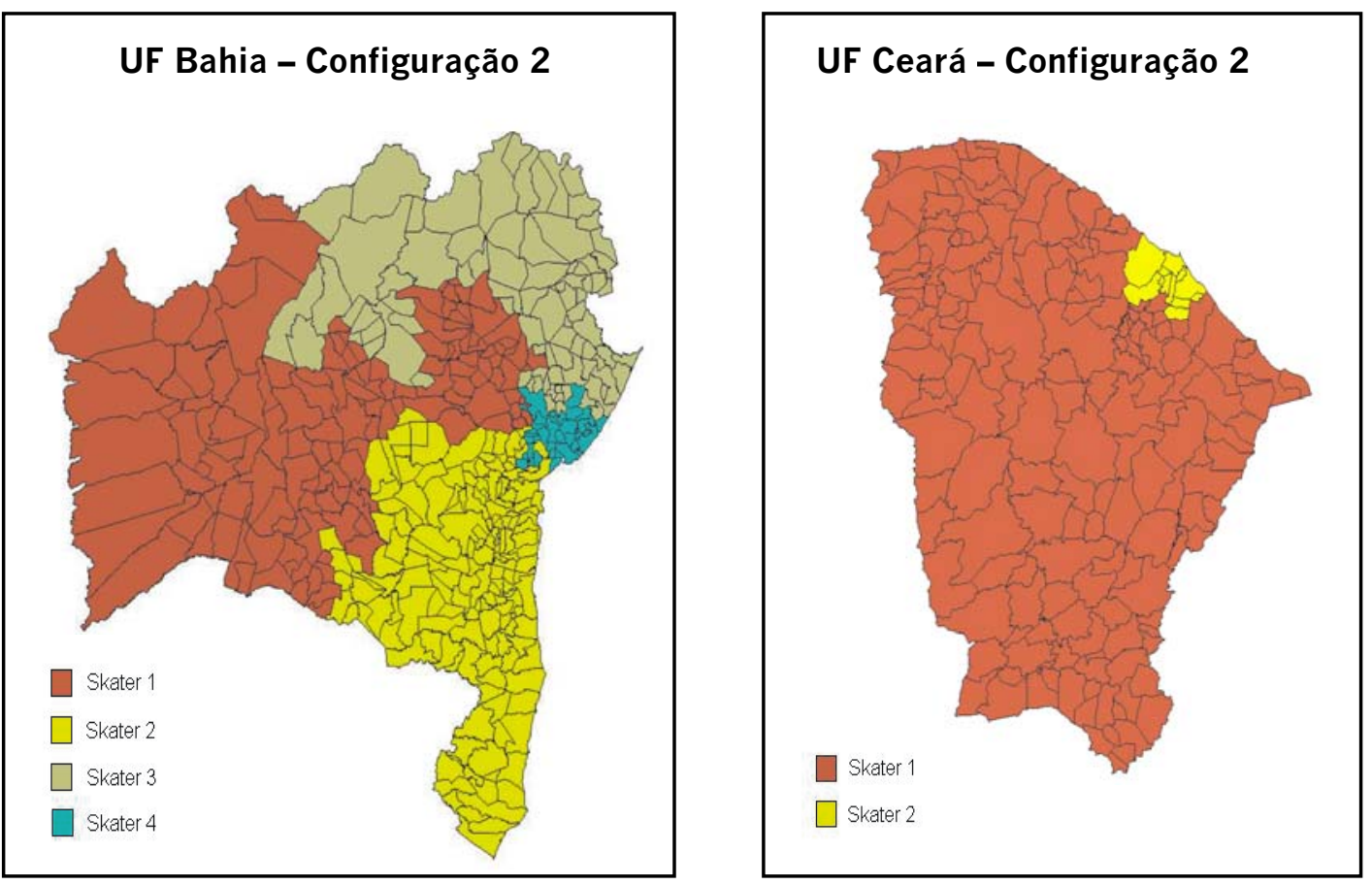
AMORIM NETO, O.; CORTEZ, B. F.; PESSOA, S. A. Redesenhando o Mapa Eleitoral do Brasil:...
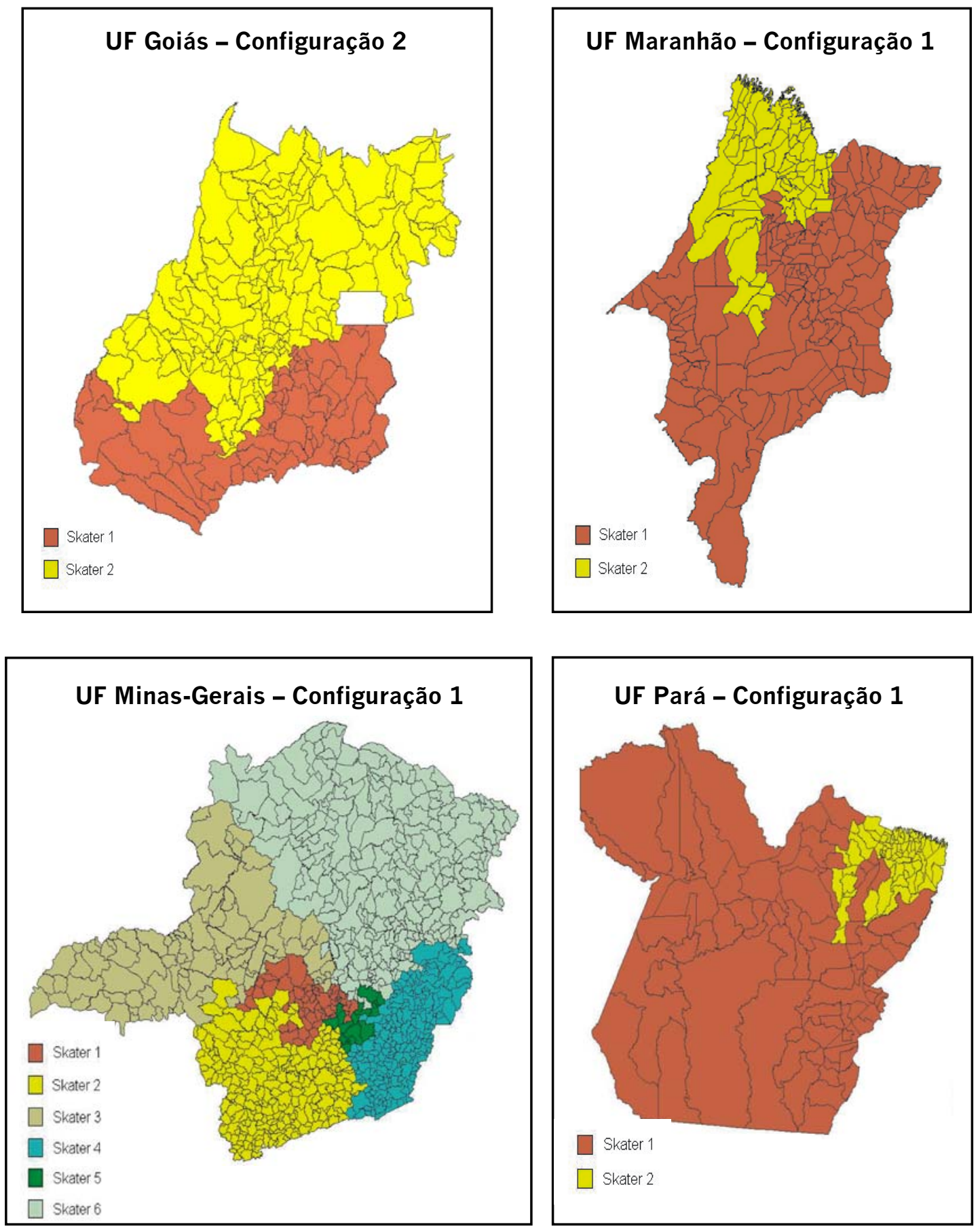

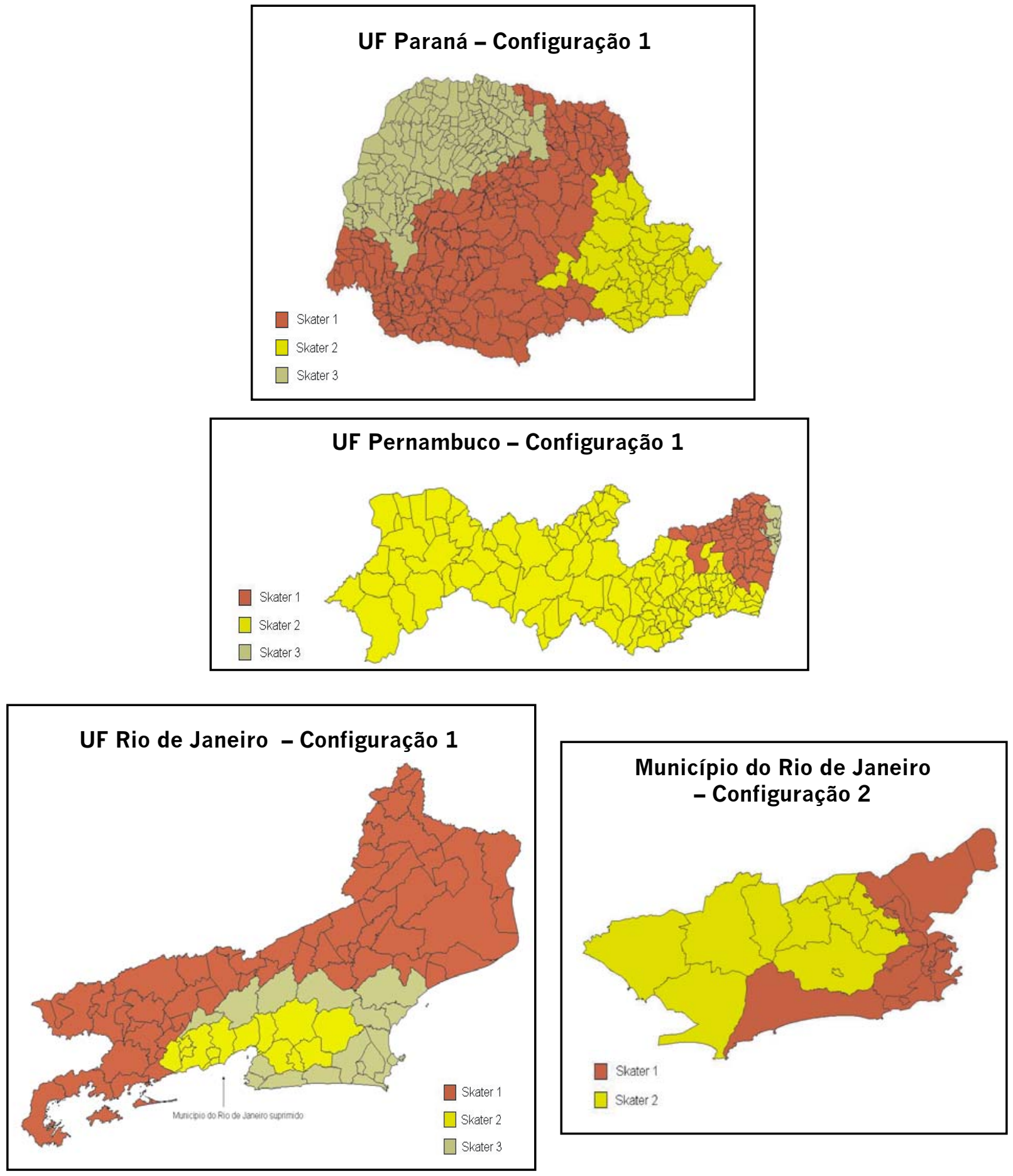
AMORIM NETO, O.; CORTEZ, B. F.; PESSOA, S. A. Redesenhando o Mapa Eleitoral do Brasil:...
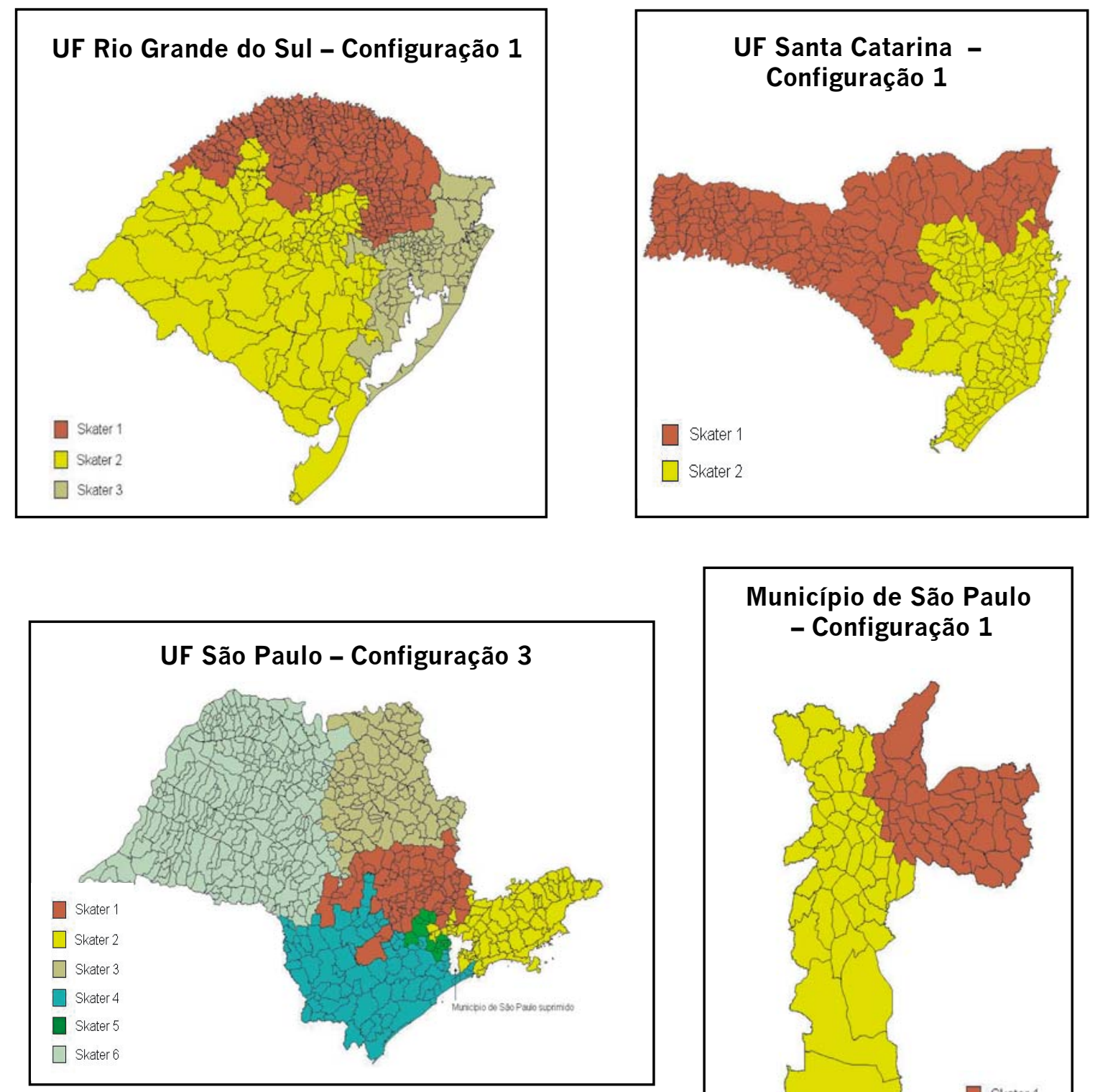
Município de São Paulo
- Configuração 1

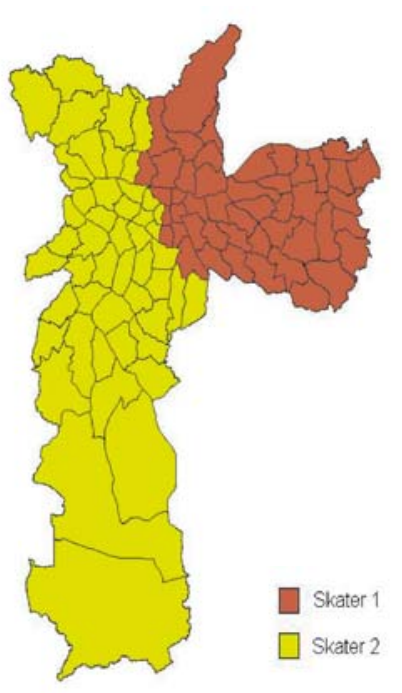


OPINIÃO PÚBLICA, Campinas, vol. 17, no 1, Junho, 2011 , p.45-75

\section{Exercício de Simulação a partir do Resultado das Eleições de 2006}

Nesta seção, apresentamos os resultados de um exercício hipotético. Supondo que os votos tenham sido os mesmos das eleições de 2006, calculamos o novo índice de fragmentação eleitoral sob o novo desenho das circunscrições eleitorais e a regra proporcional de alocação de cadeiras no interior de cada coligação eleitoral.

Para implementar o exercício, utilizamos os dados da votação de cada candidato de cada partido em cada cidade (disponível no site do TSE). A simulação é feita em três etapas. Na primeira etapa da simulação, os votos de cada coligação eleitoral em cada circunscrição eleitoral são totalizados. Na segunda etapa, o total de cadeiras de cada coligação é calculado com o auxílio do algoritmo de D'Hondt. $\mathrm{Na}$ terceira etapa, calcula-se o total de cadeiras de cada partido da coligação. Utilizamos dois procedimentos: Primeiro, aplicamos a regra vigente, segundo a qual os eleitos da coligação são os mais votados, independentemente do desempenho dos partidos; o segundo procedimento aplica a regra proporcional no interior de cada coligação. Isto é, após termos obtido o número de cadeiras de cada coligação na etapa anterior da simulação, aplicamos novamente o algoritmo de D'Hondt para conhecer o tamanho de cada bancada de cada partido no interior de cada coligação. Os mais votados de cada partido da coligação são eleitos até o limite da bancada de cada partido.

Observamos, na simulação, que alguns candidatos foram eleitos em mais de uma circunscrição eleitoral. Este foi, por exemplo, o caso do deputado Ciro Gomes, que teve expressiva votação em todo o Ceará. Para esses casos, consideramos que o candidato seria eleito pela circunscrição na qual tivesse obtido o maior número de votos. Seus votos na outra circunscrição foram considerados votos na legenda.

A Tabela 5 apresenta o índice de fragmentação partidária, tal qual medida pelo número efetivo de partidos de Laakso e Taagepera, para a bancada de cada um dos estados e para o Brasil. Há quatro situações a serem consideradas. A primeira situação, coluna (1) da Tabela 5 , apresenta o resultado da eleição divulgada pela TSE. A segunda situação, coluna (2) da Tabela 5, considera as novas circunscrições eleitorais, mantendo a regra vigente no interior de cada coligação. A terceira situação, coluna (3) da Tabela 5, considera a regra proporcional no interior de cada coligação, mas mantém as circunscrições originais, os estados da Federação. Finalmente, a quarta situação, coluna (4) da Tabela 5, considera o efeito composto das duas alterações.

A primeira linha da Tabela 5, linha Brasil, mostra que a fragmentação legislativa cairia de 9,3 para 8,2, 8,7 e 7,3, respectivamente, quando consideramos as situações (2), (3) e (4). Evidentemente, a queda da fragmentação será mais expressiva para os estados mais populosos. Para São Paulo, a queda é de $50 \%$. 
AMORIM NETO, O.; CORTEZ, B. F.; PESSOA, S. A. Redesenhando o Mapa Eleitoral do Brasil....

Queda expressiva, de 43\%, também ocorre para o Rio de Janeiro. Caso curioso que requer melhor compreensão é a expressiva queda para o Distrito Federal e Mato Grosso do Sul, respectivamente $45 \%$ e $40 \%$. Como estes estados não foram subdivididos, toda a queda que houve deveu-se à alteração na regra de divisão de cadeiras no interior das coligações.

Tabela 5

Resultado da simulação: índice de fragmentação partidária por estado

\begin{tabular}{|c|c|c|c|c|}
\hline \multirow{2}{*}{ Partido } & \multicolumn{2}{|c|}{ Coligação: Regra atual } & \multicolumn{2}{|c|}{ Coligação: Regra proporcional } \\
\hline & Estados Originais & $\begin{array}{c}\text { Novas } \\
\text { Circunscrições } \\
\end{array}$ & Estados Originais & $\begin{array}{c}\text { Novas } \\
\text { Circunscrições } \\
\end{array}$ \\
\hline & $(1)$ & (2) & (3) & (4) \\
\hline Brasil & 9,3 & 8,2 & 8,7 & 7,3 \\
\hline \multicolumn{5}{|c|}{ UFs com divisão de Distritos } \\
\hline Bahia & 5,5 & 5,8 & 4,5 & 4,6 \\
\hline Ceará & 5,5 & 6,2 & 4,2 & 5,1 \\
\hline Goiás & 5,3 & 4,0 & 5,3 & 3,9 \\
\hline Maranhão & 7,7 & 6,8 & 7,0 & 6,5 \\
\hline Minas Gerais & 9,3 & 7,3 & 8,5 & 6,6 \\
\hline Pará & 4,7 & 5,3 & 4,3 & 4,2 \\
\hline Pernambuco & 8,8 & 10,2 & 7,2 & 7,0 \\
\hline Paraná & 6,4 & 6,7 & 6,4 & 6,6 \\
\hline Rio de Janeiro & 9,9 & 5,9 & 10,4 & 5,7 \\
\hline Rio Grande do Sul & 7,4 & 5,4 & 7,2 & 5,4 \\
\hline Santa Catarina & 4,7 & 4,9 & 4,6 & 3,6 \\
\hline São Paulo & 7,4 & 4,4 & 7,7 & 3,8 \\
\hline \multicolumn{5}{|c|}{ UFs sem divisão de Distritos } \\
\hline Acre & 4,6 & 4,6 & 5,3 & 5,3 \\
\hline Alagoas & 4,8 & 4,8 & 5,4 & 5,4 \\
\hline Amazonas & 6,4 & 6,4 & 5,3 & 5,3 \\
\hline Amapá & 6,4 & 6,4 & 5,3 & 5,3 \\
\hline Distrito Federal & 5,3 & 5,3 & 2,9 & 2,9 \\
\hline Espírito Santo & 4,2 & 4,2 & 4,2 & 4,2 \\
\hline Mato Grosso do Sul & 5,3 & 5,3 & 3,2 & 3,2 \\
\hline Mato Grosso & 6,4 & 6,4 & 6,4 & 6,4 \\
\hline Paraíba & 5,1 & 5,1 & 4,5 & 4,5 \\
\hline Piauí & 6,3 & 6,3 & 6,3 & 6,3 \\
\hline Rio Grande do Norte & 6,4 & 6,4 & 5,3 & 5,3 \\
\hline Rondônia & 5,3 & 5,3 & 4,6 & 4,6 \\
\hline Roraima & 6,4 & 6,4 & 6,4 & 6,4 \\
\hline Sergipe & 4,6 & 4,6 & 4,6 & 4,6 \\
\hline Tocantins & 3,6 & 3,6 & 3,6 & 3,6 \\
\hline
\end{tabular}


A queda de duas unidades (de 9,3 para 7,3) na fragmentação mostra que esta continuaria alta, porém, com alguma redução. Além disso, esta simulação não leva em conta o chamado "efeito psicológico" que seria gerado pela redução na magnitude média das circunscrições eleitorais. O efeito psicológico diz respeito à propensão dos eleitores de abandonarem candidatos e partidos de sua primeira preferência que se tornariam inviáveis sob as novas regras aqui propostas. Sabendo disso, vários candidatos e partidos também desistiriam de concorrer. A manifestação deste efeito certamente acarretaria uma concentração ainda maior do sistema partidário.

A Tabela 6 apresenta a variação nas bancadas partidárias na Câmara sob as diferentes regras. Os partidos estão ordenados da maior para a menor bancada na situação atual, isto é, considerando a regra vigente para as coligações e que as circunscrições eleitorais são os estados da Federação (coluna [1]). Como vimos na tabela anterior, a segunda coluna considera o novo mapa eleitoral; a terceira coluna mantém o mapa eleitoral mas aplica regra proporcional no interior das coligações, e a quarta coluna considera os dois exercícios. 
AMORIM NETO, O.; CORTEZ, B. F.; PESSOA, S. A. Redesenhando o Mapa Eleitoral do Brasil....

Tabela 6

Resultado da simulação: tamanho das bancadas partidárias

\begin{tabular}{|l|c|c|c|c|}
\hline \multirow{3}{*}{ Partido } & \multicolumn{2}{|c|}{ Coligação: Regra atual } & \multicolumn{2}{c|}{ Coligação: Regra proporcional } \\
\cline { 2 - 5 } & Estados Originais & $\begin{array}{c}\text { Novas } \\
\text { Circunscrições }\end{array}$ & Estados Originais & $\begin{array}{c}\text { Novas } \\
\text { Circunscrições }\end{array}$ \\
\hline & $(1)$ & $(2)$ & $(3)$ & $(4)$ \\
\hline PMDB & 89 & 92 & 96 & 101 \\
\hline PT & 83 & 88 & 85 & 99 \\
\hline PSDB & 66 & 77 & 70 & 88 \\
\hline PFL & 65 & 76 & 67 & 70 \\
\hline PP & 41 & 38 & 33 & 34 \\
\hline PSB & 27 & 30 & 33 & 30 \\
\hline PDT & 24 & 15 & 26 & 15 \\
\hline PL & 23 & 19 & 20 & 18 \\
\hline PPS & 22 & 21 & 20 & 16 \\
\hline PTB & 22 & 17 & 21 & 14 \\
\hline PCdoB & 13 & 12 & 9 & 6 \\
\hline PV & 13 & 13 & 12 & 12 \\
\hline PSC & 9 & 6 & 7 & 4 \\
\hline PMN & 3 & 4 & 3 & 3 \\
\hline PSOL & 3 & 1 & 3 & 1 \\
\hline PTC & 3 & 1 & 3 & 1 \\
\hline PHS & 2 & 0 & 0 & 0 \\
\hline PRONA & 2 & 0 & 2 & 0 \\
\hline PAN & 1 & 3 & 0 & 1 \\
\hline PRB & 1 & 0 & 1 & 0 \\
\hline PTdoB & 1 & 0 & 1 & 0 \\
\hline PSDC & 0 & 0 & 1 & 0 \\
\hline & & & & \\
\hline
\end{tabular}

Para facilitar a visualização dos resultados, a Tabela 7 apresenta a variação no número de cadeiras de cada sigla para cada um dos exercícios hipotéticos efetuados, tomando como ponto de partida a situação real gerada pelas eleições de 2006. Os quatro maiores partidos ganharam cadeiras. Todas as demais bancadas, com a exceção do PSB, que ganhou três cadeiras, perderam. Os maiores perdedores são o PP pela direita, que perde 7 cadeiras, o PTB pela centro-direita, que perde 8 cadeiras, o PDT pela centro-esquerda, que perde 9 cadeiras, e o PC do $B$, pela esquerda, que perde 7 cadeiras. Aparentemente, a alteração na regra eleitoral não muda o equilíbrio político no Congresso. Esquerda e direita, liquidamente, nem perdem, nem ganham. Os partidos nanicos praticamente 
OPINIÃO PÚBLICA, Campinas, vol. 17, no 1, Junho, 2011 , p.45-75

desaparecem e os partidos intermediários têm o seu tamanho reduzido. Caso interessante é do PV, que perde somente uma cadeira.

Tabela 7

Resultado da simulação: variação no tamanho das bancadas partidárias

\begin{tabular}{|c|c|c|c|c|}
\hline \multirow{2}{*}{ Partido } & \multicolumn{2}{|c|}{ Coligação: Regra atual } & \multicolumn{2}{|c|}{ Coligação: Regra proporcional } \\
\hline & Estados Originais & Novos Distritos & Estados Originais & Novos Distritos \\
\hline & $(1)$ & $(2)$ & (3) & (4) \\
\hline PMDB & 0 & 3 & 7 & 12 \\
\hline PT & 0 & 5 & 2 & 16 \\
\hline PSDB & 0 & 11 & 4 & 22 \\
\hline PFL & 0 & 11 & 2 & 5 \\
\hline $\mathrm{PP}$ & 0 & .3 & .8 & .7 \\
\hline PSB & 0 & 3 & 6 & 3 \\
\hline PDT & 0 & .9 & 2 & .9 \\
\hline $\mathrm{PL}$ & 0 & -4 & -3 & .5 \\
\hline PPS & 0 & -1 & -2 & .6 \\
\hline PTB & 0 & .5 & -1 & .8 \\
\hline PCdoB & 0 & -1 & .4 & .7 \\
\hline PV & 0 & 0 & -1 & -1 \\
\hline PSC & 0 & -3 & -2 & .5 \\
\hline PMN & 0 & 1 & 0 & 0 \\
\hline PSOL & 0 & -2 & 0 & .2 \\
\hline PTC & 0 & -2 & 0 & .2 \\
\hline $\mathrm{PHS}$ & 0 & -2 & -2 & .2 \\
\hline PRONA & 0 & -2 & 0 & .2 \\
\hline PAN & 0 & 2 & -1 & 0 \\
\hline PRB & 0 & -1 & 0 & -1 \\
\hline PTdoB & 0 & -1 & 0 & -1 \\
\hline PSDC & 0 & 0 & 1 & 0 \\
\hline
\end{tabular}

\section{Conclusão}

Neste artigo, propusemos uma reforma eleitoral que altera duas variáveischave do sistema eleitoral - a magnitude média das circunscrições eleitorais e a forma de distribuir as cadeiras entre partidos coligados. Não tocamos no princípio da representação proporcional. Pelo contrário, nós o reforçamos, consoante a visão segundo a qual, apesar de todas as suas mazelas, o nosso sistema político tem um quantum de efetividade que justifica um reformismo moderado e prudente. 
Coerentemente com tal visão, estamos cientes de ser a nossa proposta apenas uma solução imperfeita para alguns excessos do nosso regime representativo. Afinal, não existe sistema eleitoral perfeito ou ideal. Qualquer que seja, gerará sempre o efeito de um cobertor curto, isto é, se cobre a cabeça, descobre os pés.

Como? De um lado, há a representação proporcional; do outro, encontra-se a representação majoritária. A representação proporcional estimula a existência de vários partidos, principalmente em sociedades heterogêneas, como enfatizamos na segunda seção do artigo. A representação majoritária tende a promover dois grandes partidos, enquanto a regra proporcional permite ao sistema partidário espelhar um amplo leque de interesses e ideologias, tornando a democracia mais representativa. A regra majoritária é, obviamente, restritiva neste aspecto, uma vez que favorece apenas poucas tendências políticas. Entretanto, por essa mesma razão, os sistemas majoritários facilitam a formação de maiorias parlamentares compostas por apenas um partido (ou monopartidárias). Nos sistemas proporcionais, as maiorias têm que ser integradas por coalizões de partidos, abrindo caminho, no Brasil, para o chamado presidencialismo de coalizão. Os governos monopartidários facilitam a vida dos eleitores porque estes sabem claramente quem é o responsável pelas decisões governamentais. Já sob governos de coalizão, o eleitor pode ficar sempre em dúvida a respeito de quem é realmente responsável pelo quê. Ou seja, o primeiro efeito do tipo "cobertor curto" gerado pelos sistemas eleitorais reside na disjuntiva entre a representatividade e a responsabilização (em inglês, accountability).

De maneira complementar, estudos recentes mostram que os países que se caracterizam por governos monopartidários são mais capazes de afetar o rumo da economia do que os países com governos de coalizão ${ }^{8}$. Os governos monopartidários, exatamente por contarem com maiorias coesas, encontram-se em melhores condições políticas para determinar o desempenho da economia do que os governos de coalizão. Contudo, sabemos que mudanças radicais são também um indicador de instabilidade. Neste sentido, justamente por serem avessos a câmbios bruscos, os países caracterizados por governos de coalizão são mais capazes de manter um ambiente econômico menos incerto do que os países com governos monopartidários. Segundo Cox e McCubbins (2001, pp. 21-63), temos, assim, o segundo efeito do tipo "cobertor curto" criado pelos sistemas eleitorais: a disjuntiva entre a capacidade de tomar decisões e a capacidade de sustentar decisões. Enquanto a regra majoritária está associada à primeira capacidade, a regra proporcional está à segunda.

Representatividade política, responsabilização governamental, a capacidade de tomar decisões, e a capacidade de sustentar decisões são valores vitais em

\footnotetext{
8 Ver ALESINA, A.; ROUBINI, N. e COHEN, G., 1997.
} 
qualquer regime democrático. No entanto, eles, juntos, não podem ser maximizados ao mesmo tempo. Desenhar instituições políticas significa, portanto, optar por alternativas que maximizem certos valores e minimizem outros. Ou seja, a grande questão a ser colocada em um debate sobre reforma eleitoral é saber quais valores devem ser maximizados no momento histórico que vive o país. Por exemplo, segundo Melo, no começo da década de 1930, quando o Brasil adotou a representação proporcional com lista aberta, esta

“[...] não resultou de uma inovação aleatória, e sim de um cálculo deliberado das elites políticas progressistas da República Velha. Afinal o que se queria derrotar e varrer do país com esta reforma? $\mathrm{Na}$ realidade, o sistema foi criado para barrar o poder discricionário do poder executivo no nível federal e estadual. Sua introdução tinha um duplo alvo: o sistema de partido único nos estados [...] e o poder pessoal do presidente no plano nacional. O propósito fundamental da reforma era garantir o pluralismo e a competição política, garantindo a voz das minorias" (MELO, 2011).

No começo da década de 1930, fazia todo sentido estabelecer um sistema eleitoral altamente permissivo, dado que "O propósito fundamental [...] era garantir o pluralismo e a competição política." Porém, no começo do século XXI, está claro que fomos longe demais em tais garantias. Assim, com base na visão do sistema político brasileiro oferecida na segunda seção deste artigo, cremos ser fundamental - hoje - aumentar a responsabilização governamental. Nosso sistema eleitoral favorece demasiadamente o quesito representatividade, a ponto de termos uma das legislaturas mais fragmentadas do mundo. Ainda que não seja o caso de se abandonar a representação proporcional, é imperativo facilitar a vida do eleitor, oferecendo-Ihe um quadro partidário mais compacto e nítido por meio da redução do número de partidos.

Para reduzir o número de partidos, existem dois métodos principais: a imposição de uma rigorosa cláusula de barreira e a redução da magnitude média das circunscrições eleitorais. Neste artigo, advogamos a segunda alternativa, mas desaconselhamos a sua forma mais radical, nomeadamente, a adoção de distritos uninominais ou suas variantes. Defendemos e operacionalizamos aqui a ideia de reduzir moderadamente aquela magnitude por meio de um novo desenho das circunscrições eleitorais do país (os estados), além de propormos uma regra proporcional de alocação de cadeiras dentro das coligações eleitorais.

Quanto ao segundo efeito do tipo "cobertor curto", o quadro é mais complexo. Enquanto o Brasil necessita, em algumas áreas, de maior capacidade de tomar decisões (ex.: o ajuste fiscal, a reforma da previdência, a reforma tributária), 
em outras, o país precisa de maior capacidade de sustentar decisões (ex.: a manutenção de uma baixa taxa de inflação). Porém, independentemente da posição que se tenha a respeito deste cobertor curto, nada ganhamos por termos uma das legislaturas mais fragmentadas do mundo ${ }^{9}$. Sabemos hoje que o nosso presidencialismo de coalizão, apesar das suas mazelas, pode ser efetivo, mas não precisa sê-lo a um custo tão alto, custo gerado, em boa medida, pela alta fragmentação legislativa. É hora, pois, de mudar mas de maneira incremental.

\section{Referências bibliográficas}

ABRANCHES, S. H. "Presidencialismo de coalizão: o dilema institucional brasileiro", Dados, 31: 5-38, 1988.

ALESINA, A.; ROUBINI, N. e COHEN, G. Political cycles and the macroeconomy, Cambridge: The MIT Press, 1997.

AMES, B. The deadlock of democracy in Brazil, Ann. Arbor: The University of Michigan Press, 2001.

AMORIM NETO. O. e COX, G. W. "Electoral institution cleavage structure, and the numbers of parties", American Journal of Political Science 41(1): 149-174, 1997.

AMORIM NETO. O. Presidencialismo e Governabilidade nas Américas, Rio de Janeiro: FGV Editora, p. 71-96; 97-120, 2006.

BENOIT, K. "The endogeneity problem in electoral studies: a critical re-examination of Duverger's mechanical effect”, Electoral Studies 21(1): 35-46, 2002.

CARVALHO, N. R. E no Início Eram as Bases: Geografia Política do Voto e Comportamento Legislativo no Brasil, Rio de Janeiro: Editora Revan, 2003.

COX, G. W. Making Votes Count: Strategic Coordination in the World's Electoral Systems, New York: Cambridge University Press, 1997.

COX, G. W. e MCCUBBINS, M. D. "The Institutional Determinants of Economic Policy, In: HAGGARD, S. e MCCUBBINS, M. D. (Orgs.), Presidents, Parliaments, and Policy, Cambridge: Cambridge University Press, pp. 21-63, 2001.

DUVERGER, M. Les Partis Politiques, Paris: Armand Collin, 1951.

\footnotetext{
${ }^{9}$ O número efetivo de partidos gerados pelas eleições de 2010 para a Câmara dos Deputados é de 10,4,
} o mais alto da nossa história. 
FIGUEIREDO, A. e LIMONGI, F. "Poder de agenda na democracia brasileira: desempenho do governo no presidencialismo pluripartidário", In: Reforma Política, lições da história recente. SOARES, A. D. G. e RENNÓ, R. L. (orgs.), Rio de Janeiro: FGV Editora, p. 249-280, 2006.

LAAKSO, M. e TAAGEPERA, R. "Effective Number of Parties: A Measure with Application to West Europe", Comparative Political Studies 12:3-27, 1979.

LIJPHART, A. Electoral Systems and Party Systems: A Study of Twenty-Seven Democracies 1945-1990, New York: Oxford University Press, 1951.

LIMA JÚNIOR, O. B. e SANTOS, F. "O Sistema Proporcional no Brasil: Lições de Vida”, In: LIMA JÚNIOR, O. B. (org.), Sistema Eleitoral Brasileiro: Teoria e Prática, Rio de Janeiro: Rio Fundo, p. 152, 1991.

LIMONGI, F. "Presidencialismo e governo de coalizão", In: AVRITZER, L. e ANASTÁSIA, F. (orgs.), Reforma política no Brasil, Belo Horizonte: Editora UFMG, p. 237.257, 2006.

MELO, M. A. "Her Majesty the President of Brazil," Valor Econômico, São Paulo, 10 de maio, p. A6, 2011.

MONROE, B. L. and ROSE, A. G. "Electoral System and Unimagined Consequences: Partisan Effect of District Proportional Rule", American Journal of Political Science, 46(1): 67-89, 2002.

MUKHERJEE, B. "Political Parties and the Size of Government in Multiparty Legislatures", Comparative Political Studies 36(6): 699-728, 2003.

NICOLAU, J. Multipartidarismo e Democracia: Um Estudo Sobre o Sistema Partidário Brasileiro (1985-94), Rio de Janeiro: FGV Editora, 1996.

NICOLAU, J. "Voto Personalizado e Reforma Eleitoral no Brasil" In: Reforma Política, lições da história recente SOARES, A. D. G. e RENNÓ, R. L. (orgs.), Rio de Janeiro: FGV Editora, p. 23-33, 2006.

ORDESHOOK, P. C. e SHVETSOVA, O. V. "Ethnic heterogeneity, district magnitude, and the number of parties", American Journal of Political Science 38(1): 100-123, 1994.

RAE, D. W. The Political Consequences of Electoral Laws, New Haven: Yale University Press, 1967. 
SAMUELS, D. "Financiamento de campanha no Brasil e proposta de reforma", In: Reforma Política, lições da história recente SOARES, A. D. G. e RENNÓ, R. L. (orgs.), Rio de Janeiro: FGV Editora, p. 133-153, 2006.

. "Presidentialism and Accountability for the Economy in Comparative Perspective", American Political Science Review 98(3): 425-436, 2004.

SANTOS, F. O Poder Legislativo no Presidencialismo de Coalizão, Belo Horizonte: Editora UFMG, p. 29.110, 2003.

SCHRÖDER, B. Regimes, Governos e Carga Tributária no Brasil (1946-2007),

Dissertação de Mestrado, Escola de Pós-Graduação em Economia, Fundação Getulio Vargas, Rio de Janeiro, 2009.

TAAGEPERA, R. e SHUGART, M. S. Seats and Votes: The Effects and Determinants of Electoral Systems, New Haven: Yale University Press, 1989.

. "Predicting the number of parties: a quantitative model of Duverger's mechanical effect," American Political Science Review 87(2): 455-464, 1993.

TAVITS, M. "Clarity of Responsibility and corruption", American Journal of Political Science 51(1): 218-229, 2007.

Octavio Amorim Neto - oamorim@fgv.br

Bruno Freitas Cortez - bruno.cortez@ibge.gov.br

Samuel de Abreu Pessoa - samuel.pessoa@fgv.br

Recebido para publicação em dezembro de 2010.

Aprovado para publicação em maio de 2011. 